\title{
The roles of integrins in cancer
}

\author{
Donatella Valdembri ${ }^{1,2^{*}}$ Guido Serini ${ }^{1,2^{*}}$ \\ ${ }_{1}$ Candiolo Cancer Institute - Fondazione del Piemonte per l'Oncologia (FPO) - IRCCS, Candiolo (TO), Italy \\ ${ }_{2}$ Department of Oncology, University of Torino School of Medicine, Candiolo (TO), Italy
}

\begin{abstract}
Integrin-mediated adhesion of cells to the extracellular matrix (ECM) is crucial for the physiological development and functioning of tissues but is pathologically disrupted in cancer. Indeed, abnormal regulation of integrin receptors and ECM ligands allows cancer cells to break down tissue borders, breach into blood and lymphatic vessels, and survive traveling in suspension through body fluids or residing in metabolically or pharmacologically hostile environments. Different molecular and cellular mechanisms responsible for the modulation of integrin adhesive function or mechanochemical signaling are altered and participate in cancer. Cancer development and progression are also bolstered by dysfunctionalities of integrin-mediated ECM adhesion occurring both in tumor cells and in elements of the surrounding tumor microenvironment, such as vascular cells, cancer-associated fibroblasts, and immune cells. Mounting evidence suggests that integrin inhibitors may be effectively exploited to overcome resistance to standard-of-care anti-cancer therapies.
\end{abstract}

\section{Keywords}

Integrins, cancer

\section{Peer Review}

The peer reviewers who approve this article are:

1. Vasiliki Gkretsi, Biomedical Sciences Program, Department of Life Sciences, School of Sciences, European University Cyprus, Nicosia, Cyprus

Competing interests: No competing interests were disclosed.

2. Paul Mathew, Division of Hematology-Oncology, Tufts Medical Center, Boston, USA

Competing interests: No competing interests were disclosed.

3. Stéphanie Kermorgant, Spatial Signalling Team, Barts Cancer Institute, Queen Mary University of London, London, UK Competing interests: No competing interests were disclosed. 
*Corresponding author: Guido Serini (guido.serini@ircc.it); Donatella Valdembri (donatella.valdembri@ircc.it)

Competing interests: The authors declare that they have no competing interests.

Grant information: Work in the authors' laboratories was supported by Fondazione AIRC IG grants \#13016, \#16702, and \#21315 (to GS) and \#20366 (to DV); Fondazione AIRC under 5 per Mille 2018 - ID. 21052 program - P.I. Comoglio Paolo, G.L. Serini Guido (to GS); FPRC-ONLUS grant “MIUR 2010 Vaschetto - 5 per mille 2010 MIUR” (to GS); Telethon Italy (GGP09175) (to GS); and Associazione “Augusto per la Vita” (to GS). The funders had no role in study design, data collection and analysis, decision to publish, or preparation of the manuscript.

Copyright: (C) 2021 Serini G et al. This is an open access article distributed under the terms of the Creative Commons Attribution License, which permits unrestricted use, distribution, and reproduction in any medium, provided the original work is properly cited.

How to cite this article: Valdembri D and Serini G. The roles of integrins in cancer. Faculty Reviews 2021 10:(45) https:/doi.org/10.12703/r/10-45

Published: 07 May 2021, Faculty Reviews 10:(45) https://doi.org/10.12703/r/10-45 


\section{Introduction}

In multicellular organisms, the interaction of cells with the surrounding extracellular matrix $(E C M)$ is crucial for the physiology and integrity of tissues. In the mammalian cell, integrins are the main ECM receptors providing a link between the external matrix scaffold and the internal actin cytoskeleton mediated mainly by their cytosolic adaptor proteins, among which talin and kindlin play pivotal roles ${ }^{1,2}$.

The $18 \alpha$ integrin and eight $\beta$ integrin distinct subunits are assembled in various combinations and form 24 transmembrane heterodimers that are endowed with binding specificity for different ligands $s^{3,4}$. Integrin receptors are regulated at transcriptional and translational levels in a tissue-specific manner. Moreover, endosomal trafficking back and forth from the plasma membrane, surface-polarized distribution, and dynamic localization at ECM contact sites are all crucial regulatory steps of integrin-mediated adhesion. Integrin functions are disrupted in many pathological settings, such as cancer. Indeed, alterations in cell adhesion and migration are involved in almost every phase of cancer progression, from tumor onset to metastasis. Moreover, abnormal expression of integrins has been correlated to several types of cancer and varies depending on the extent of neoplastic progression and prognosis. In addition, altered endocytosis and recycling kinetics, often observed in cancer cells, result in derailed cell surface and endosomal integrin signaling, thus providing cancer cells with oncogenic and invasive abilities $^{3,4}$. Finally, although increasing evidence points to integrins as potential therapeutic targets in several cancer types, clinical trials so far have achieved poor outcomes ${ }^{3,4}$.

To develop new and effective pharmacological anti-cancer strategies, investigators need to thoroughly understand the contribution of integrin activation and signaling to the different steps of tumor progression. Recent reviews ${ }^{3,4}$ have analyzed in detail the functions and roles that integrins play in cancer development, progression, and treatment. Here, we will focus mainly on the most recent advances that have further unveiled the molecular and cellular mechanisms by which integrins affect the biology and therapy of cancer.

\section{Regulation of integrin function and signaling in cancer cells}

Integrin conformational activation

Integrins fluctuate between a low-affinity bent-closed conformation and a high-affinity extended-open conformation, the shift being defined as integrin activation. Despite the large number of integrin interactors, which constitute the so-called "adhesome", talin and kindlin are the only two integrin-binding adaptor proteins known to be indispensable for integrin activation ${ }^{5}$. Talin recruitment to the membrane-proximal NPXY motif of the $\beta$ integrin cytoplasmic tail disrupts the transmembrane association between integrin $\alpha$ and $\beta$ subunits, inducing the extension of the extracellular portion and the opening of the ligand-binding pocket $^{1}$. Kindlin family members (kindlin-1, -2, and -3) assist talin-dependent stabilization of the extended-open conformation of integrins and their clustering. Binding the cytosolic membrane-distal NPXY motif of integrin $\beta$ subunits, kindlins function as protein-protein interaction hubs capable of recruiting molecular complexes and allowing integrin connection to the actin cytoskeleton and cell spreading (Figure 1$)^{2}$.

All three kindlin isoforms have been involved in cancers, as their expression levels have been found to be altered compared with the corresponding normal tissue in several cancer types. Kindlin-1 is frequently overexpressed in lung, breast, bladder, and colon cancer $^{6}$ and its oncogenic potential strongly depends on transforming growth factor beta (TGF $\beta$ ) signaling. Kindlin-2, the most broadly distributed member of the family, exerts a tumor type-dependent promoting or inhibiting function. In breast ${ }^{7}$ and bladder ${ }^{8}$ cancer, pancreatic ductal adenocarcinoma (PDAC) ${ }^{9}$, and malignant mesothelioma, kindlin-2 expression directly correlates with tumor progression and invasion ${ }^{10}$. Most likely, kindlin-2 exerts its oncogenic function in these tumors by promoting epithelial-to-mesenchymal transition (EMT), fostering ERK and Akt activation, and TGF $\beta$ signaling. In contrast, in colorectal carcinomas and serous epithelial ovarian cancers, kindlin-2 suppresses tumor invasion and progression ${ }^{11,12}$. Interestingly, kindlin-2 displays integrin-dependent and -independent roles in cancer development. In esophageal squamous cell carcinoma cells, kindlin-2/ $\beta 1$ integrin/AKT signaling activation promotes tumor invasion ${ }^{13}$; in prostate cancer cell lines, inhibition of the kindlin-2/ $/ 31$ integrin pathway enhances the sensitivity to chemotherapeutic agents ${ }^{14}$. In contrast, in breast cancer cells, TGF $\beta$ signaling increases the kindlin-2-mediated but integrin-independent expression of colony-stimulating factor 1 (CSF-1) that recruits macrophages, driving tumor progression ${ }^{15}$. Moreover, by binding nuclear p53 and impairing the transcription of the senescence inducers SerpinB2 and p21, kindlin-2 promotes breast cancer cell growth ${ }^{16}$. Kindlin-3, which is expressed mainly in the hematopoietic system, has been found to support the progression of acute myeloid leukemia and chronic myeloid leukemia $(\mathrm{CML})^{17}$. In a CML mouse model, the loss of kindlin-3 abrogates integrin-mediated adhesion of leukemia stem cells to the bone marrow niche, triggering their release into circulation and impairing their proliferation, survival, and metastatic dissemination $^{18}$.

\section{Integrins and mechanosensing}

Cells explore the biophysical properties of the surrounding microenvironment through integrin receptors and respond by activating intracellular signals and adapting their behavior accordingly. This process, termed mechanotransduction, is often dysregulated during cancer progression, which usually is characterized by increasing tissue stiffness due to abnormal ECM deposition, organization, and rehandling ${ }^{19}$. In particular, stiff substrates promote an increased force transmission that supports the reprogramming of oncogene-expressing cells toward a tumorigenic phenotype ${ }^{20}$. Stiff matrices induce integrin- and F-actin-dependent activation of the transcription factors YAP and TAZ, whose target genes account for a substantial fraction of the transcriptional responses downstream of oncogenic signaling ${ }^{21}$. Recently, tumor ECM meshworks enriched 


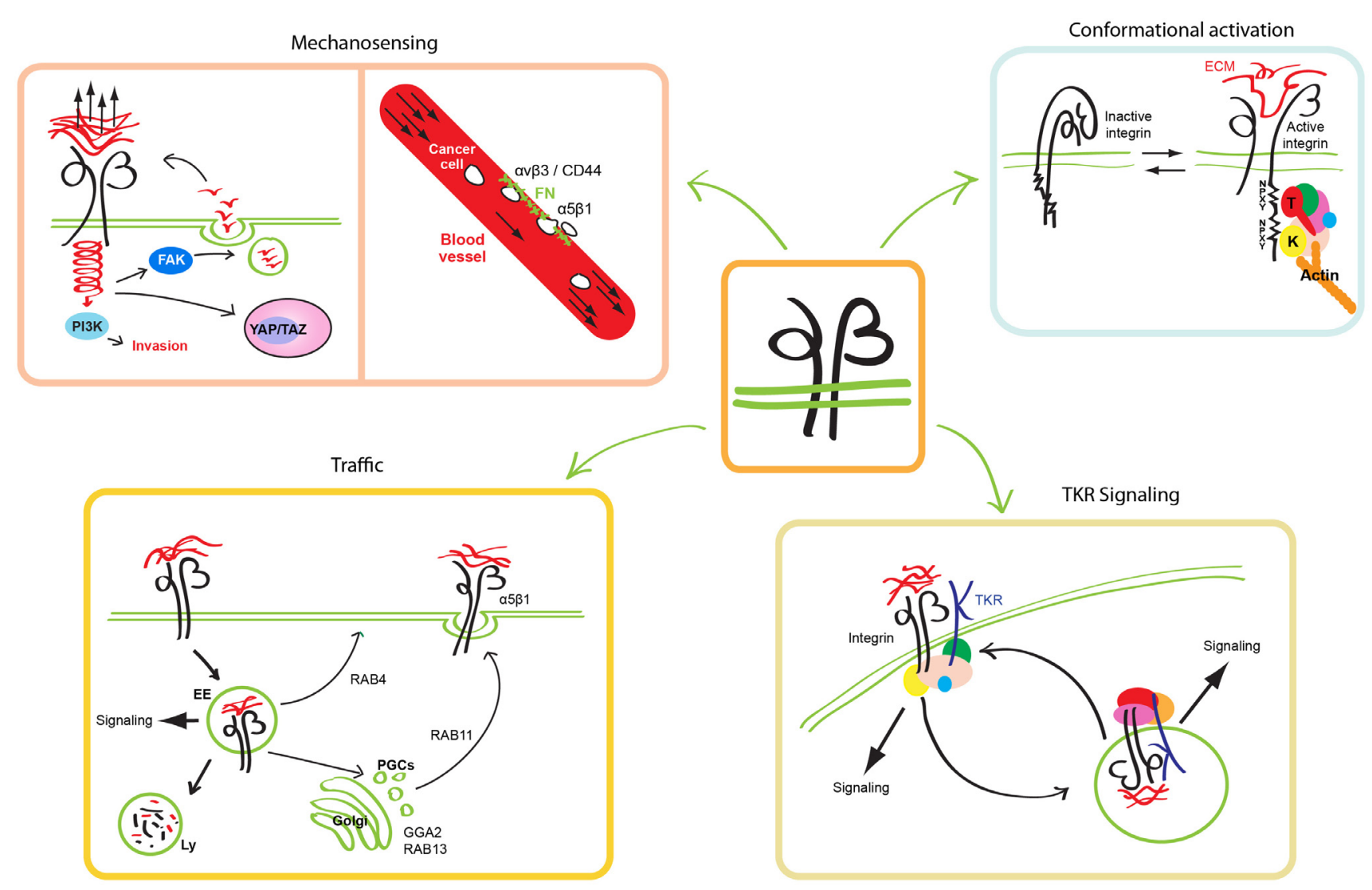

Figure 1. Integrin function is regulated by conformational activation and vesicular traffic and is crucially involved in mechanosensing and TKR signaling. Integrin $\alpha \beta$ heterodimers shift between a low-affinity bent-closed (inactive) conformation and a high-affinity extendedopen (active) conformation. Many interactors (collectively identified as "the adhesome") bind the cytoplasmic portion of conformationally active integrins; among them, talin $(\mathrm{T})$ and kindlin $(\mathrm{K})$ are the only two $\beta$ subunit adaptor proteins found to be indispensable for integrin activation (upper right pane/). Integrins sense the biophysical properties of the surrounding microenvironment. Stiff substrates promote an increased force transmission and YAP/TAZ translocation to the nucleus, whose target genes promote cancer progression. In blood vessels, low hemodynamic forces promote the binding of circulating tumor cells to fibronectin (FN) secreted by vascular endothelial cells; in this process, $\alpha \vee \beta 3$ integrin/CD 44 first and $\alpha 5 \beta 1$ integrin later promote cancer cell arrest. Stiff extracellular matrix (ECM) sustains PI3K and FAK signaling (upper left panel). Integrins are constitutively endocytosed and recycled back to the cell surface in a short loop (RAB4-dependent) or long loop (TGN and RAB11-dependent) or sorted for degradation in lysosomes (Ly). The escape of integrins from the degradative pathway sustains their signaling from endosomes (EE) and promotes their recycling to the surface (lower left pane/). Mutual regulation between integrin and growth factor TKR signaling and traffic is crucial for cancer development and metastatic dissemination (lower right pane/). TKR, tyrosine kinase receptor; PGC, post-Golgi carrier.

by agrin $^{22}$ and periostin ${ }^{23}$ have been discovered to exploit integrin-activated signaling pathways that impinge on YAP/TAZ-driven gene transcription (Figure 1).

Mechanical properties of tumor ECM are also influenced by collagen fiber crosslinking that requires fibronectin (FN). ECM rich in collagen-FN favors exposure and ligation of the FN cell adhesion synergy site by $\alpha 5 \beta 1$ integrin and enhances zyxin and vinculin recruitment, finally sustaining PI3K-dependent tumor cell invasion ${ }^{24}$. Increased extracellular tension can also be due to the bulkiness of the cancer cell glycocalyx. In recurrent glioblastoma multiforme (GBM), high levels of glycoconjugates induce a mesenchymal stem-like phenotype and promote integrin adhesion assembly and FAK-mediated signaling, which in turn sustain the expression of several glycoproteins in a self-reinforcing mechanism ${ }^{25}$. Furthermore, mechanosensing is involved in cancer metastasis. Likely owing to conformational activation properties of adhesion receptors, such as integrin catch bonding behavior, pN-range blood flow hemodynamic forces promote the binding of circulating tumor cells to vascular endothelial cells $(\mathrm{ECs})^{26}$. In particular, halting of circulating cancer cells occurs in vascular regions where lower shear forces favor the luminal deposition of $\mathrm{FN}$; it is a two-step process, first mediated 
by $\mathrm{CD} 44$ and $\alpha v \beta 3$ integrin weak adhesions and then stabilized by $\alpha 5 \beta 1$ integrin-dependent high-strength adhesion (Figure 1) ${ }^{27}$.

In addition to stiffness, the geometric physical features of ECM may influence tumor progression. For example, alterations of ECM architecture can promote vasculogenic mimicry, a cancer cell-based blood supply system that can take place independently of angiogenesis and is associated with poor prognosis. Collagen matrices with small pores and short fibers upregulate $\beta 1$ integrin expression and increase motility and expression of vasculogenesis-associated genes in tumor cells ${ }^{28}$.

\section{Integrin traffic}

Integrin traffic contributes to ECM adhesion turnover and ultimately regulates cell migration and invasion. According to the canonical model, integrins are constitutively endocytosed in a clathrin- or caveolin-dependent manner and are recycled back to the cell surface or sorted for degradation ${ }^{29}$. Integrin recycling to the cell surface follows two different routes: a short Rab4-mediated loop or a long Rab11-dependent loop ${ }^{30}$. The latter is the preferential pathway followed by active $\alpha 5 \beta 1$ integrins and is crucial for cancer cell migration and colonization of metastatic sites. In breast cancer cells, silencing of the Rab11 regulator Rabgap1 impairs active $\beta 1$ integrin recycling and migration ${ }^{31}$, whereas Rab11b upregulation during early adaptation to the brain metastatic sites favors successful $\beta 1$ integrin recycling to the surface and interaction with the ECM, promoting mechanotransduction-activated survival ${ }^{32}$. Rab11b-dependent active $\beta 1$ integrin basolateral recycling exploits the trans-Golgi network (TGN) secretory pathway ${ }^{33}$, and GGA2 (Golgi-associated, gamma adaptin ear-containing, ARFbinding protein 2) and Rab13 are key specificity determinants of this route (Figure 1$)^{34}$.

The escape of integrins from the degradative pathway sustains their endosomal signaling and promotes their recycling to the surface. In breast cancer cells, upon $17 \beta$-estradiol stimulation, FN-bound active $\beta 1$ integrins are internalized together with estrogen receptor alpha $(E R \alpha)$ and recycled to the plasma membrane in a Rab11-dependent manner, thus preventing $\mathrm{ER} \alpha$ lysosomal degradation ${ }^{35}$. Consistently, an FN-rich matrix induces tamoxifen resistance in breast cancer and correlates with lower patient survival ${ }^{36}$. In small-cell lung cancer, low expression levels of cullin 5 (CUL5) and suppressor of cytokine signaling 3 (SOCS3) correlate with a highly metastatic phenotype and poor prognosis. Mechanistically, CUL5 and SOCS3 deficiency impairs the formation of the cullin-RING E3 ubiquitin ligase complex, preventing $\beta 1$ integrin degradation and stabilizing downstream FAK/SRC signaling ${ }^{37}$. Moreover, $\beta 1$ integrin-promoted FAK signaling on endosomes ${ }^{38,39}$ and sustained $\beta 1$ integrin co-internalized tyrosine kinase receptor (TKR) signaling ${ }^{39}$ suppress cell death due to ECM detachment (anoikis).

Intercellular communication through extracellular vesicledependent integrin-mediated endocytosis and recycling also plays a critical role in metastatic dissemination ${ }^{40}$. $\alpha v \beta 3$ integrin is required to allow extracellular vesicle-dependent enhancement of colony-forming capacity in cultured breast cancer cells ${ }^{41}$. Whereas heparan sulfate proteoglycans act as receptors responsible for extracellular vesicle tethering and capture on the surface of breast cancer cells, $\alpha v \beta 3$ integrin mediates the ensuing FAK- and dynamin-driven endocytosis ${ }^{41}$. PDAC cells carrying loss-of-function p53 mutation (mutp53) instead release exosomes that contain high levels of podocalixin and can make other organs more favorable to metastatic seeding ${ }^{42}$. Specifically, the uptake of mutp53 PDAC exosomes by otherwise-normal fibroblasts localized in distant districts from the site of origin, such as the lungs, promotes $\alpha 5 \beta 1$ integrin recycling and the deposition of a highly pro-invasive $\mathrm{ECM}^{42}$.

\section{Integrins and growth factor receptor signaling}

It is well established that interconnections between integrin and growth factor TKR signaling and traffic are crucial for cancer development and metastatic dissemination (Figure 1$)^{43}$. Among TKRs, ligand-activated epidermal growth factor receptor (EGFR) was previously reported to associate with several integrin subunits and act upstream to modulate their adhesive and signaling functions ${ }^{44}$. Recently, the functional meaning of previously reported ${ }^{45}$ non-canonical ligand-independent signaling of EGFR family members downstream of ECM-bound integrins was deciphered ${ }^{46}$. It turns out that, owing to transient interactions with integrins at peripheral nascent adhesion sites of spreading cells, EGFR and human epidermal growth factor receptor 2 (HER2) get activated by SRC family kinases and signal to promote further spreading and rigidity-sensing contractions on stiff but not soft substrates ${ }^{46}$. Importantly, loss of rigidity-sensing contractions confers to cancer cells the ability to grow on soft substrates, independently from stable integrin-mediated anchorage to the $\mathrm{ECM}^{47}$.

In triple-negative breast cancers (TBNCs), which are very aggressive tumors characterized by the lack of ER, progesterone receptor (PR), and HER2, high expression and reciprocal compensation between $\beta 1$ integrin and EGFR signaling synergize to support tumor progression and metastasis ${ }^{48}$. Ectopic expression of the secreted ECM protein TINAGL1 (tubulointerstitial nephritis antigen-like 1) suppresses TNBC progression by binding and inhibiting the signaling of both $\beta 1$ integrin and $\mathrm{EGFR}^{48}$. On the surface of breast, pancreatic, and lung cancer cells, galectin-3 binds and elicits the anchorage-independent clustering of $\alpha v \beta 3$ integrin along with the downstream activation of KRAS, a driver of resistance to anti-EGFR therapy ${ }^{49}$. Galectin-3-induced $\alpha v \beta 3$ integrin clustering drives KRAS addiction in tumor cells, and galectin-3 inhibition represents an actionable target to treat KRAS G12D-bearing cancers ${ }^{50}$.

Interestingly, the laminin receptor $\beta 4$ integrin binds to several TKRs, including EGF-R, HER2 (also known as ERBB2), MET, and RON, sustaining their signaling pathways ${ }^{51-54}$. Upon ligand stimulation, these TKRs activate integrin-associated SRC-family kinases (SFKs) promoting the phosphorylation of the $\beta 4$ cytotail and TKR-bound interactors by SFKs. These 
multiple phosphorylations create an amplified docking platform potentiating TKR downstream pathways favoring hemidesmosome disassembly and cancer cell invasion ${ }^{55,56}$. These findings suggest the possible benefit of the combined use of anti-cancer agents able to interfere with integrin signaling function in combination with the impairment of their adhesive properties.

\section{Integrins and cancer cell metabolism}

Recent evidence sheds further light on the critical role played by integrin and ECM stiffness in shaping metabolic behaviors of cancer cells $\mathrm{s}^{57,58}$. Mammalian target of rapamycin (mTOR) and PI3K signaling allow tumor cells to grow in a nutrient-deprived environment and to overcome anoikis in anchorage-independent conditions ${ }^{59}$. Although PI3K/mTOR inhibition results in apoptosis of ECM-detached tumor cells, ECM-adherent tumor cells respond to nutrient deprivation by inducing the expression of pro-survival and anti-apoptotic proteins, such as BCL2, EGFR, and insulin-like growth factor 1 receptor $(\mathrm{IGF} 1 \mathrm{R})^{60}$. Starved mammary epithelial cells increase $\beta 4$ integrin expression and endocytosis of $\beta 4$ integrin-bound laminin, whose degradation in lysosomes increases the availability of amino acids and enhances mTORC1 signaling, thus preventing cell death (Figure 2) ${ }^{61}$. Because $\beta 4$ integrin overexpression is a feature of several human cancers $^{62}$, it will be

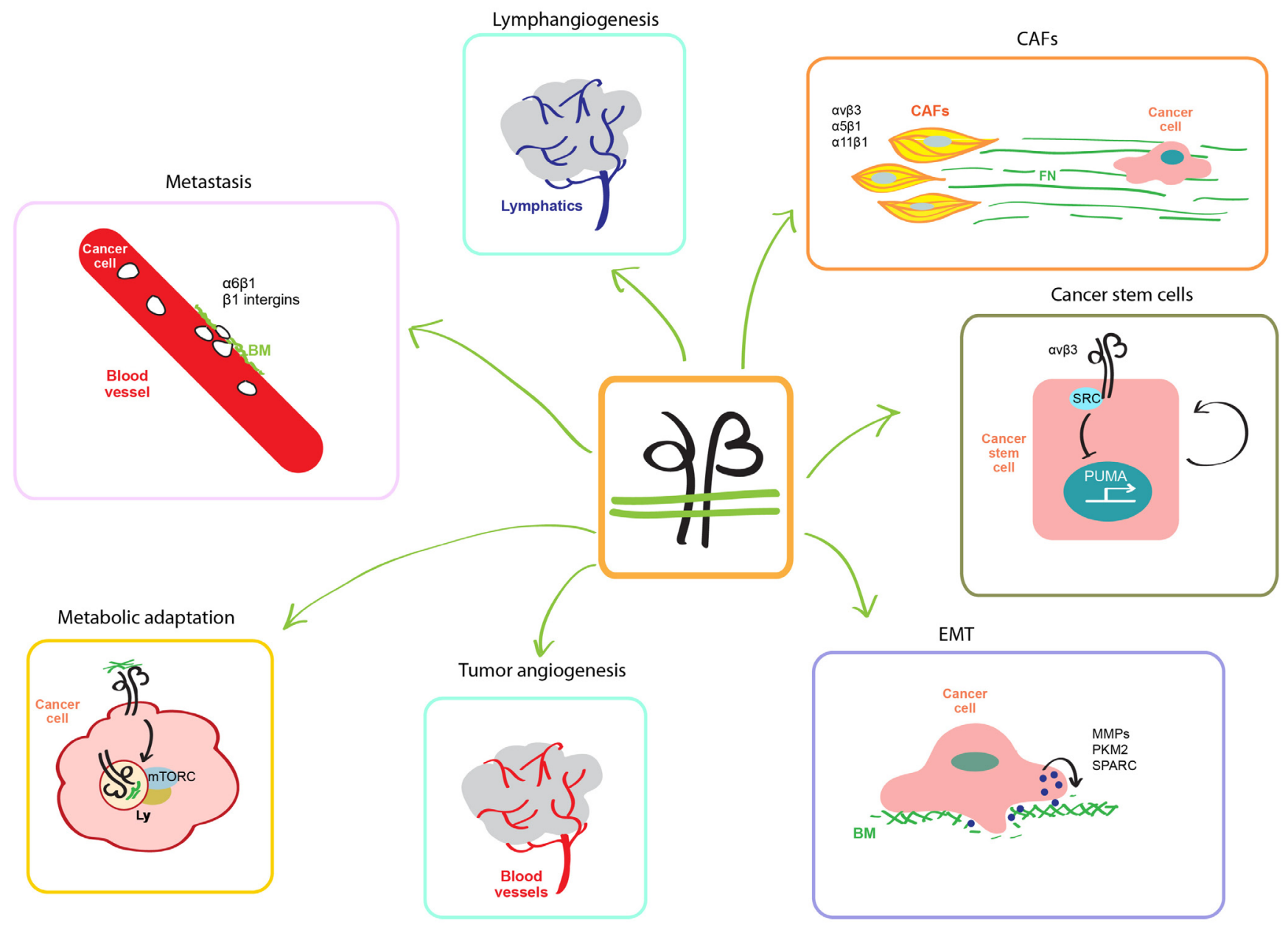

Figure 2. Integrins are involved in several steps of cancer progression. Integrins and stiff extracellular matrix regulate the metabolic behavior of cancer cell and mTORC activation on lysosomes (Ly). Integrins promote the formation of new blood and lymphatic vessels that support tumor growth, invasion, and metastatic dissemination. During epithelial-to-mesenchymal transition (EMT), integrins sustain the migratory phenotype of cancer cells, also characterized by an increased secretion of matrix metalloproteinases (MMPs), the M2 isoform of pyruvate kinase (PKM2), and the matricellular protein SPARC (secreted protein acidic and rich in cysteine). In breast cancer, $\alpha \vee \beta 3$ integrins induce the transcription of the proapoptotic gene PUMA (p53-upregulated modulator of apoptosis), thus supporting tumor stemness. In the tumor microenvironment, CAFs produce and polymerize via $\alpha 5 \beta 1$ high amounts of aligned fibronectin (FN) fibers along which cancer cells migrate directionally in an $\alpha v \beta 3$-dependent manner. Furthermore, $\alpha 11 \beta 1$ integrin- and PDGFR- $\beta$-expressing CAFs promote breast cancer progression. Integrin-mediated interactions with laminin of blood vessel basal membrane (BM) also promote cancer cell dissemination and seeding in distant organs. 
interesting to investigate whether $\beta 4$ integrin-dependent laminin internalization represents a key amino acid source in tumors.

Activated $\alpha 5 \beta 1$ integrins move from peripheral nascent adhesions to central fibrillary adhesions in a tensin-dependent manner. In ovarian cancer cells, Arf4-driven internalization from fibrillary adhesions of ligand-engaged $\alpha 5 \beta 1$ integrins triggers their endosomal transport to lysosomes, promoting mTOR activation ${ }^{63}$. In contrast, the formation of fibrillary adhesions in fibroblasts is prevented by the energy sensor 5 '-prime-AMP-activated protein kinase (AMPK), which downregulates the expression of tensin ${ }^{64,65}$. AMPK is activated by the cellular AMP/ATP ratio increase that occurs in conditions of nutrient depletion. Hence, AMPK and mTOR, by responding to opposite alterations in nutrient availability, are reciprocally regulated and control tensin-coupled $\alpha 5 \beta 1$ integrin-driven FN fibrillogenesis. The AMPK-regulated turnover of the FN matrix may be relevant for tumor-CAF crosstalk in that CAF-derived FN could be a source of metabolic energy for cancer cells.

In a HER2-driven mouse model of breast cancer, a stiff ECM induces insulin receptor (IR) recruitment to focal adhesions, thus allowing the formation of IR/integrin complexes and preventing IR lysosomal degradation ${ }^{66}$. Double $\beta 1 / \beta 3$ integrin genetic ablation in this breast cancer model results in defective IR/AKT/mTORC1 signaling and inhibition of both tumor onset and metastatic dissemination to lungs ${ }^{66}$. On a related note, within the proneural and classic subgroups of patients with GBM, a subpopulation exists in which high $\alpha v \beta 3$ integrin levels activate a PAK4-mediated YAP/TAZ signaling pathway that in turn enhances the expression of the insulin-regulated and neuron-specific glucose transporter GLUT3. High $\alpha v \beta 3$ integrin/ GLUT3-addicted GBM cells survive in a glucose-deprived milieu and are resistant to conventional therapies ${ }^{67}$.

Finally, it is becoming apparent that the availability of specific nutrients in different districts of the organism may draw a heterogeneous landscape of area-specific environmental pressures that are crucial for the selection of metastatic sites by circulating cancer cells. For example, the abundance of pyruvate in lung interstitial fluids supports the production of $\alpha$-ketoglutarate that in breast cancer cells increases the activity of the collagen prolyl-4-hydroxylase enzyme. As a result, pyruvate promotes collagen crosslinking and ECM remodeling by breast cancer cells in this metastatic niche, thus specifically improving their survival in lungs ${ }^{68}$.

\section{Integrin in the context of cancer progression and therapy \\ Integrins and tumor blood vessels}

Vascular endothelial growth factor $(\mathrm{VEGF})^{69}$ and integrins ${ }^{3}$ drive the formation of nutrient-providing blood vessels that support tumor growth and progression. Angiogenesis depends on dynamic cycles of EC adhesion to deadhesion from the ECM that crucially depends on the endosomal traffic of integrins ${ }^{70}$. In this regard, the Arg-Gly-Asp (RGD) motif-containing and integrin-binding epidermal growth factor-like protein 7 (EGFL7) is emerging as a novel important regulator of tumor angiogenesis (Figure 2) $)^{71}$. For instance, ECs of glioblastoma (GBM) blood vessels express high levels of EGFL7 that binds, impairs the endocytosis, and promotes the accumulation of $\alpha v \beta 3$ (and $\alpha 5 \beta 1$ ) integrin on the surface of $\mathrm{ECs}^{72}$. In GBM, endothelial EGFL7-integrin signaling promotes the formation of new blood vessels and therapeutic EGFL7 blockade synergizes with anti-VEGF to more effectively impair tumor angiogenesis and growth ${ }^{72}$.

The stiffening of the ECM of tumor microenvironment (TME) also promotes angiogenesis ${ }^{73}$, likely via a mechano-signaling network triggered by Agrin, a heparan sulfate proteoglycan that both cancer cells ${ }^{22}$ and $\mathrm{ECs}^{74}$ secrete. Agrin is well known for its ability to bind to low-density lipoprotein receptor-related protein 4 (LRP4) receptor that, activating muscle-specific kinase (MUSK), triggers the aggregation of acetylcholine receptors and the formation of neuromuscular junctions ${ }^{75}$. During cancer progression, Agrin-bound LRP4 associates instead with $\beta 1$ integrins and elicits FAK signaling that in turn fosters tumor angiogenesis and growth by stabilizing VEGFR-2 protein levels in $\mathrm{ECs}^{74}$.

Recently, Wong et al. showed how tumor growth also depends on novel integrin-dependent non-canonical function of pericytes that act as paracrine sources of tumor trophic factors ${ }^{76}$. Indeed, in different human cancers, the simple lack of $\beta 3$ integrin in blood vessel mural cells correlates with a larger tumor size and clinically more aggressive phenotype ${ }^{76}$. Mechanistically, the absence of $\beta 3$ integrin in pericytes, though not altering blood vessel number and function, upregulates the FAK-MET-AKT-NFKB-driven production of the cytokine CCL2 that in turn sustains tumor growth in a CCR2 receptor-dependent manner ${ }^{76}$.

\section{Integrins and tumor progression}

During tumor progression, transcription factors of the SNAIL, TWIST, and ZEB gene families give rise to the EMT transcriptional program, which is characterized by the detachment from the epithelial basement membrane $(\mathrm{BM})$ and the acquisition of a $\beta 1 / \beta 3$ integrin and $\mathrm{FN}$-driven migratory phenotype, endowing cancer cells with increased invasive ability and resistance to therapies ${ }^{77}$. During EMT, the increased transcription of genes encoding for matrix metalloproteinases (MMPs) facilitates the degradation of BM by cancer cells ${ }^{77}$. The noncanonically secreted M2 isozyme of pyruvate kinase (PKM2) accumulates in the extracellular fluids of several human cancers and promotes cancer progression ${ }^{78}$. In lung cancer cells, secreted PKM2 was found to bind $\beta 1$ integrins and elicit the activation of a FAK/SRC/ERK pathway that facilitates metastasis, at least in part by increasing MMP-9 transcription ${ }^{79}$.

EMT is also supported by matricellular proteins, such as secreted protein acidic and rich in cysteine (SPARC) that, in addition to binding and activating integrin signaling, crosslinks and increases the stiffness of TME ECM (Figure 2) ${ }^{80}$. In addition, 
SPARC drives cancer EMT by modulating TME immune cells. Indeed, in high-grade breast cancers containing high amounts of SPARC, the deposition of abundant collagen bundles induces the COX-2-dependent expression of granulocyte-macrophage colony-stimulating factor (GM-CSF) and interleukin-6 (IL-6) in tumor cells attracting $\mathrm{CD}_{3} 3^{+}$myeloid-derived suppressor cells responsible for cancer cell EMT and chemoresistance $^{81}$. In addition, EMT promotes the generation of self-renewing cancer stem cells (CSCs) that actively sustain tumor development and growth through molecular mechanisms that are under investigation ${ }^{82}$. In breast CSCs, $\alpha v \beta 3$ integrin-activated SRC kinase signals to suppress via SLUG (also known as SNAI2) the transcription of the proapoptotic gene p53-upregulated modulator of apoptosis (PUMA), thus supporting tumor stemness (Figure 2) ${ }^{83}$. Significantly, pharmacological $\alpha v \beta 3 /$ SRC blockade fosters breast CSC apoptosis and lessens pulmonary metastasis by re-establishing PUMA expression ${ }^{83}$.

\section{Integrins and tumor microenvironment}

Adhesive and humoral interactions with TME cells (for example, fibroblasts, blood and lymphatic ECs, and immune cells) play key roles in supporting cancer metastasis colonization of distant sites throughout the body. First identified as "myofibroblasts" in healing wounds ${ }^{84}$ and then in breast cancer ${ }^{85}$, CAFs and their role in tumor progression and invasion started being appreciated and investigated in only the last two decades ${ }^{86}$. CAFs release diffusible factors that are not sufficient to elicit cancer cell invasion, which instead crucially relies on their ability to remodel the ECM (Figure 2) ) $^{87,88}$. In the extracellular microenvironment, $\alpha 5 \beta 1$ integrin binds dimeric soluble $\mathrm{FN}$ and promotes its polymerization in a matrix that functions as a scaffold driving type I collagen fibrillogenesis ${ }^{89}$. In vitro, CAFs isolated from human tumors produce and polymerize-via coordinated $\alpha 5 \beta 1 / \alpha v \beta 3$ integrinbinding and platelet-derived growth factor receptor alpha (PDGFR $\alpha$ )-mediated actomyosin contractility-an abundant anisotropically oriented FN fibrillar network along which cancer cells migrate directionally in an $\alpha v$ integrin-dependent manner ${ }^{87,88}$. Furthermore, aligned FN fibrils characterize invasion sites in human prostatic ductal adenocarcinoma and $\mathrm{PDAC}^{88}$. Analyses of the preclinical MMTV-PyMT (mouse mammary tumor virus polyoma middle tumor antigen) model and human samples unveiled the crucial role played by a subset of CAFs expressing the collagen-binding integrin $\alpha 11 \beta 1$ and PDGFR $\beta$ in breast cancer progression ${ }^{90}$. Mechanistically, the PDGF-BB-dependent interaction of $\alpha 11 \beta 1$ integrin with PDGFR $\beta$ activates, through JNK, the production by CAFs of the matricellular protein tenascin $\mathrm{C}^{80}$, which in turn promotes breast cancer cell invasion ${ }^{90}$.

Different cancer types may employ diverse (circulation or lymphatic) routes for metastatic dissemination, depending on the embryonic derivation and the anatomy of the tissue of origin. Moreover, studies in mouse models have shown that cancer cells first can metastasize to lymph nodes and next enter the circulation by intravasating through lymph node blood vessels $^{91,92}$. Accordingly, lymphangiogenesis frequently precedes metastatic invasion of solid tumor-draining lymph nodes (Figure 2) ${ }^{93}$. Lymphatic ECs of cancer-associated lymph nodes de novo express the $\alpha \mathrm{IIb}$ integrin subunit that, together with $\beta 3$, gives rise to the main fibrinogen receptor ${ }^{94}$. Indeed, $\alpha \mathrm{IIb} \beta 3$-expressing lymphatic ECs adhere to fibrinogen in vitro and fibrinogen associates with $\alpha \mathrm{IIb} \beta 3^{+}$lymphatic ECs in tumor-draining lymph nodes in vivo, pointing to a role of $\alpha \operatorname{IIb} \beta 3$ integrin in cancer-linked lymphatic remodeling ${ }^{94}$. Concerning the mechanisms supporting lymphatic invasion, $\alpha 6 \beta 4$ integrin-expressing macrophages in TBNCs adhere to BM laminin 5 of the lymphovasculature and release TGF $\beta 1$, thus eliciting RhoA-dependent lymphatic EC contraction that favors tumor intravasation ${ }^{95}$.

\section{Integrins and metastatic dissemination}

Integrins are involved in each of the major steps of solid tumor metastatic progression from cancer cell breaching the $\mathrm{BM}$, entering into blood or lymphatic vessels (intravasation), anchorage-independent survival in the circulation, exit from vasculature (extravasation), and colonization of distant organs. At least two independent studies ${ }^{96,97}$ have shown how metastatic cancer cell dissemination and seeding in distant organs, such as brain, lung, and liver, can rely on the integrin-mediated interaction with BM laminin on the abluminal side of blood vessel ECs, a tumor survival and progression strategy that requires blood vessel co-option (Figure 2) ) $^{98}$ Indeed, upon extravasation, metastasis-initiating cancer cells colonize different organs by competing with pericytes for the perivascular niche and adopting a common pathway in which L1CAM supports BM-driven $\beta 1$ integrin activation and ILK/YAP signaling ${ }^{96}$. Similarly, acute lymphoblastic leukemia (ALL) metastatization to central nervous system (CNS) leptomeninges depends on the PI3K $\delta$-dependent expression of $\alpha 6 \beta 1$ integrin that supports ALL cell extravasation and migration along laminin of $\mathrm{BM}$ that coats the external surface of meningeal blood vessels ${ }^{97}$. Pharmacological inhibition of PI3K $\delta$, which downregulates $\alpha 6$ integrin expression, or $\alpha 6$ integrin direct blockade significantly impairs ALL spreading along $\mathrm{CNS}^{97}$ as well as resistance to chemotherapy in mouse models of B-cell ALL (B-ALL) ${ }^{99}$. These data, along with the observation that high expression levels of $\alpha 6$ integrin at the time of diagnosis in patients with high-risk B-ALL predict resistance to standard-of-care therapy, suggest that $\alpha 6$ integrin may represent a novel therapeutic target in ALL. Similarly, in the perivascular niche, $\alpha v \beta 3$ and $\alpha 4 \beta 1$ integrin-mediated interaction of bone marrow-disseminated breast cancer cells with EC-derived ligands (that is, von Willebrand factor and VCAM-1 respectively) protects them from chemotherapy, whose cytotoxic and antimetastatic effects can be unleashed by the co-administration of $\alpha v \beta 3$ or $\beta 1$ integrin antagonists ${ }^{100}$. Likewise, inhibition of integrin function in TME cells can be effective in improving the efficacy of chemotherapy, at least in some cancer types such as PDAC, which is characterized by the abundant accumulation of stromal ECM. Samples from patients with PDAC display significantly high levels of $\alpha 5$ integrin expression in stromal 
cells that inversely correlate with overall survival. ITGA5 gene silencing in pancreatic stellate cells and functional inhibition of $\alpha 5$ integrin with a peptidomimetic compound strongly reduced desmoplasia and significantly increase the therapeutic efficacy of gemcitabine in co-injection in patient-derived xenograft tumor models of PDAC ${ }^{101}$.

Investigations of in vitro and in vivo models of head and neck squamous cell carcinoma (HNSCC) revealed that $\beta 1$ integrins can favor the activation of the classic non-homologous end joining (NHEJ) mechanism of repair of DNA double-strand breaks (DSBs) induced by radiotherapy ${ }^{102} \cdot \beta 1$ integrins indeed connect poly-ADP-ribose polymerase $1 / 2$ (PARP1/2) to DSB sensor proteins $\mathrm{Ku}-70 / 80$, but not to DNA single-strand break (SSB) sensors, through still-unknown mechanisms. Of note, even if $\beta 1$ integrin blockade increases HNSCC radiosensitivity, the additive effect observed after the simultaneous inhibition of PARP1/2 suggests that $\beta 1$ integrins promote the activation of some but not all mechanisms of DNA repair. Interestingly, it was recently reported that simultaneous but not single inhibition of $\alpha v$ and $\beta 1$ integrins effectively overcomes the radioresistance, prevents the metastatic escape, and enhances the long-term survival of sarcoma and melanoma mouse models ${ }^{103}$. In this regard, it may be worth investigating whether $\alpha \mathrm{v}$ and $\beta 1$ integrins signal to promote the activity of different DNA repair machineries.

\section{Targeting integrins in anti-cancer therapy}

Integrins were considered attractive pharmacological targets for drugs aimed at hampering several key processes in cancer progression, such as cell proliferation, survival, and migration. However, despite initial encouraging results in preclinical studies, monoclonal antibodies, antagonist peptides, and small molecules used as inhibitors of integrin functions were largely unsuccessful in clinical trials and so far none of them has been recognized as an effective anti-cancer drug (see Table 1 for examples of integrin-inhibiting agents) ${ }^{104}$. Targeting integrins to improve the delivery of anti-tumor agents or to image cancer lesions represents a novel and promising approach. Cyclic RGD-based nanocarriers coupled to anti-cancer agents have been used successfully to target $\alpha \mathrm{v} \beta 3$ integrin-overexpressing angiogenic ECs or cancer cells ${ }^{105}$. These carriers, being internalized via receptor-mediated endocytosis, allow an efficient intracellular delivery of drugs and their efficacy has been further improved when exploited in dual targeting. The simultaneous delivery of peptides directed against $\alpha v \beta 3$ integrin and P-selectin ${ }^{106}$ or $\mathrm{CD} 44^{107}$ displayed increased anti-angiogenic and anti-cancer efficacy when compared with single targeting strategies. Interestingly, an $\alpha v \beta 6$ integrin-specific peptide was coupled to a photosensitizer and used to increase the efficacy of photodynamic therapy in a lung mouse model. Local activation by light irradiation of the compound induces the production of reactive oxygen species, necrotic cancer cell death, and dendritic cell- and $\mathrm{CD}^{+} \mathrm{T}$ cell-mediated response $^{108}$. Tracers targeting $\alpha v \beta 3, \alpha 5 \beta 1$, and $\alpha v \beta 6$ have also been developed and exploited for in vivo tumor imaging by magnetic resonance imaging, positron emission tomography, and computer tomography ${ }^{109-111}$. These techniques are potentially relevant for the initial diagnosis, staging, and monitoring of the disease as well as intraoperative visualization of tumor margins to guarantee their complete resection ${ }^{112}$.

Because integrins have a crucial role in cancer development, the failure of numerous clinical studies inhibiting their functions has been disappointing and opens new questions that still lack conclusive answers. Although many integrin $\alpha \beta$ heterodimers have been implicated in tumor development, only a few of them have been exploited as therapeutic targets in clinical trials. Moreover, functional redundancy of integrins suggests the possible efficacy of therapies simultaneously targeting multiple integrin heterodimers. Conventional integrininhibiting anti-cancer drugs have been conceived for the ability to impair ligand binding. However, when bound to high-affinity compounds, integrins could still promote intracellular signals and survival of cells in ECM-detached conditions. Identifying molecules capable of interfering with the recruitment of cytoplasmic interactors, such as talins, kindlins, ILK, or FAK, may represent an alternative rationale for the selection of novel pharmacological classes of integrin inhibitors.

Although most integrin inhibitors were used mainly for single-agent anti-angiogenic therapies, other components of TME, other than blood vessels, such as infiltrating immunosuppressive cells, whose inhibition might improve cancer-directed immune response ${ }^{113}$, and CAFs could represent novel targets for integrin-based therapies. For example, by impairing the adhesion of monocytes to the vascular endothelium and their extravasation into tumor tissues, $\alpha 4 \beta 1$ integrin antagonists were found to hamper macrophage colonization of tumors and angiogenesis ${ }^{114}$. In addition, targeting $\alpha \mathrm{v}$ and $\beta 1$ integrin subunits hinders ECM deposition and remodeling by CAFs, ultimately lessening cancer aggressiveness ${ }^{115}$. The peculiar expression of $\alpha \mathrm{v} \beta 6$ integrin, highly upregulated in colon, lung, breast, cervix, ovaries/fallopian tube, pancreas, and head and neck solid tumors, while physiologically absent in adult epithelial tissues, renders this receptor an extremely attractive target for immunotherapeutic strategies such as chimeric antigen receptor T-cell adoptive immunotherapy. Moreover, the latencyassociated peptide (LAP), which maintains TGF $\beta$ in its inactive form, is a major ligand of $\alpha v \beta 6$ integrin. Because the binding to $\alpha v \beta 6$ integrin induces LAP conformational changes releasing active TGF $\beta$, which signals to suppress T-helper 2 cells and activate MMPs, functional blocking of this integrin may hamper tumor progression by improving immunotherapy and decreasing matrix degradation and cell invasion ${ }^{116,117}$. Finally, a further strategy to improve the impact of integrintargeting therapies is represented by the identification of new suitable biomarkers to be employed for successfully selecting patients who would benefit more from this type of pharmacological treatment. 

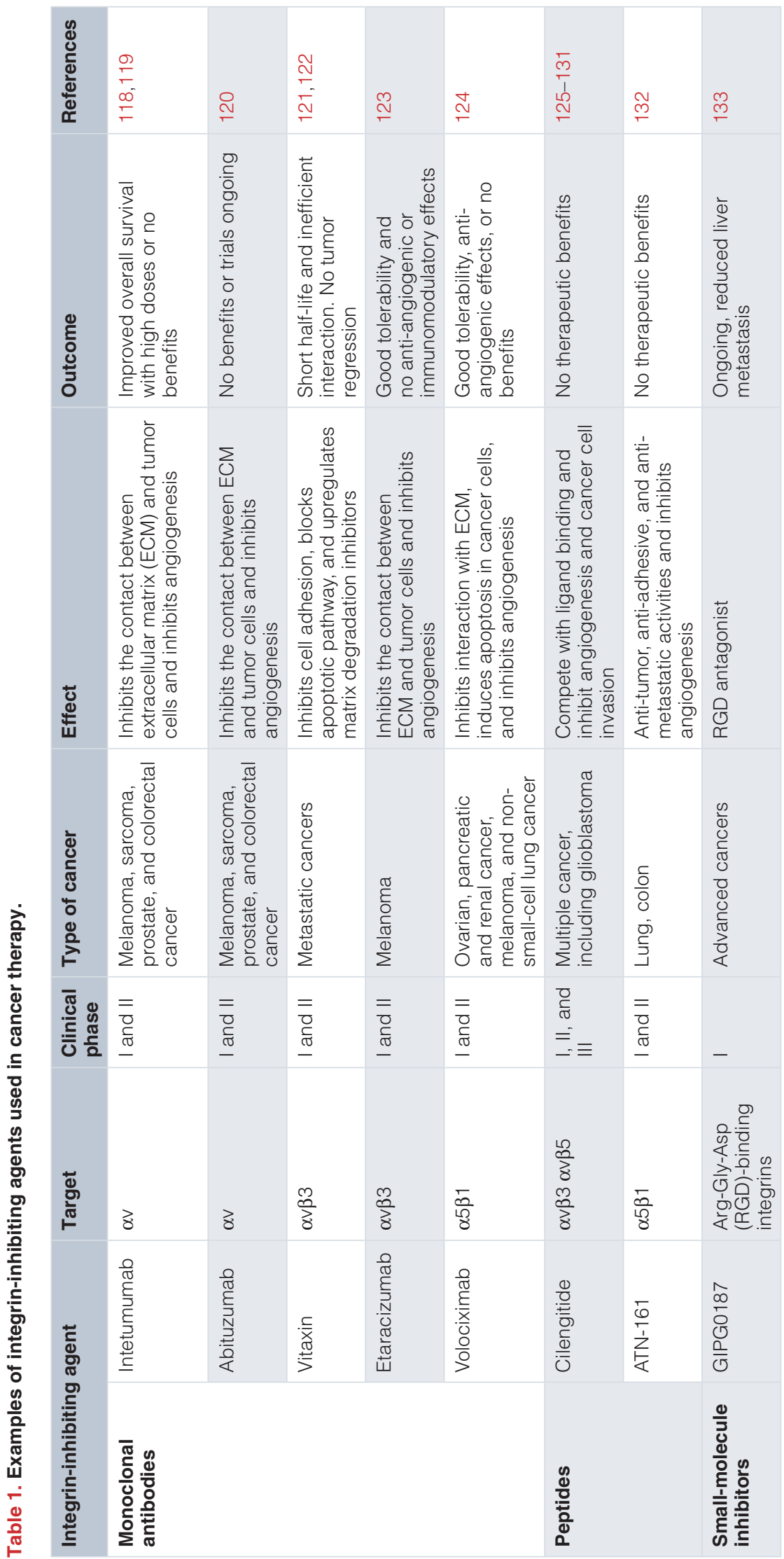


\section{Summary}

Several recent studies have provided evidence regarding the involvement of integrins and their upstream modulators and downstream effectors in the development, progression, and resistance to standard-of-care therapies in different cancer types. In addition to affecting cell adhesion, motility, invasion, and metastatic dissemination, integrins were reported to have an impact on cancer cell stemness, anchorage-independent growth, anoikis, and metabolism. The disappointing outcomes of the numerous clinical trials employing integrin inhibitors as single anti-cancer agents increase the possibility that these therapies are more effectively exploited in combination.
Indeed, likely because of the unique ability of integrins to simultaneously transduce mechanical and biochemical signal and functionally interact with several other receptor systems (for example, growth factor and $\mathrm{G}$ protein-coupled receptors) and metabolic and signaling pathways (for example, DNA damage repair), their pharmacological inhibition may be particularly effective in rescuing cancer resistance to chemotherapy, targeted therapy, and radiotherapy. Further comprehensive characterization of the molecular and cellular mechanisms by which integrins control cancer cell behavior will allow a more effective set of strategies to exploit integrin inhibition in anti-cancer therapies.
1. Calderwood DA, Campbell ID, Critchley DR: Talins and kindlins: Partners in integrin-mediated adhesion. Nat Rev Mol Cell Biol. 2013; 14(8): 503-17. PubMed Abstract | Publisher Full Text | Free Full Text

2. Sun Z, Costell M, Fässler R: Integrin activation by talin, kindlin and mechanical forces. Nat Cell Biol. 2019; 21(1): 25-31. PubMed Abstract | Publisher Full Text

3. Hamidi $\mathrm{H}$, Ivaska J: Every step of the way: Integrins in cancer progression and metastasis. Nat Rev Cancer. 2018; 18(9): 533-48. PubMed Abstract | Publisher Full Text | Free Full Text | Faculty Opinions Recommendation

4. Cooper J, Giancotti FG: Integrin Signaling in Cancer: Mechanotransduction, Stemness, Epithelial Plasticity, and Therapeutic Resistance. Cancer Cell. 2019; 35(3): 347-367.

PubMed Abstract | Publisher Full Text | Free Full Text

5. Theodosiou M, Widmaier M, Böttcher RT, et al:: Kindlin-2 cooperates with talin to activate integrins and induces cell spreading by directly binding paxillin. eLife. 2016; 5: e10130.

PubMed Abstract | Publisher Full Text | Free Full Text

6. Sin S, Bonin F, Petit V, et al: Role of the focal adhesion protein kindlin-1 in breast cancer growth and lung metastasis. J Natl Cancer Inst. 2011; 103(17): 1323-37.

PubMed Abstract | Publisher Full Tex

7. Gozgit JM, Pentecost BT, Marconi SA, et al:: Use of an aggressive MCF-7 cell line variant, TMX2-28, to study cell invasion in breast cancer. Mol Cancer Res. 2006; 4(12): 905-13.

PubMed Abstract | Publisher Full Text

8. Talaat $\mathrm{S}$, Somji $\mathrm{S}$, Toni $\mathrm{C}$, et al:: Kindlin-2 expression in arsenite- and cadmiumtransformed bladder cancer cell lines and in archival specimens of human bladder cancer. Urology. 2011; 77(6): 1507.e1-7.

PubMed Abstract | Publisher Full Text | Free Full Text

9. Mahawithitwong $\mathrm{P}$, Ohuchida $\mathrm{K}$, Ikenaga $\mathrm{N}$, et al.: Kindlin-2 expression in peritumoral stroma is associated with poor prognosis in pancreatic ductal adenocarcinoma. Pancreas. 2013; 42(4): 663-9. PubMed Abstract | Publisher Full Text

10. An Z, Dobra K, Lock JG, et al.: Kindlin-2 is expressed in malignant mesothelioma and is required for tumor cell adhesion and migration. Int $J$ Cancer. 2010; 127(9): 1999-2008. PubMed Abstract | Publisher Full Text

11. Ren C, Du J, Xi C, et al.: Kindlin-2 inhibits serous epithelial ovarian cancer peritoneal dissemination and predicts patient outcomes. Biochem Biophys Res Commun. 2014; 446(1): 187-94. PubMed Abstract | Publisher Full Text

12. Ren $\mathrm{Y}$, Jin $\mathrm{H}, \mathrm{Xue} \mathrm{Z}$, et al:: Kindlin-2 inhibited the growth and migration of colorectal cancer cells. Tumour Biol. 2015; 36(6): 4107-14. PubMed Abstract | Publisher Full Text

13. Zhang H-F, Alshareef $\mathrm{A}$, Wu C, et al:: Loss of miR-200b promotes invasion via activating the Kindlin-2/integrin $\beta 1 / A K T$ pathway in esophageal squamous cell carcinoma: An E-cadherin-independent mechanism. Oncotarget. 2015; 6(30): 28949-60.

PubMed Abstract | Publisher Full Text | Free Full Text

14. Sossey-Alaoui K, Plow EF: miR-138-Mediated Regulation of KINDLIN-2
Expression Modulates Sensitivity to Chemotherapeutics. Mol Cancer Res. 2016; 14(2): 228-38.

PubMed Abstract | Publisher Full Text | Free Full Text

15. Sossey-Alaoui K, Pluskota E, Bialkowska K, et al: Kindlin-2 Regulates the Growth of Breast Cancer Tumors by Activating CSF-1-Mediated Macrophage Infiltration. Cancer Res. 2017; 77(18): 5129-5141.

PubMed Abstract | Publisher Full Text | Free Full Text

16. Sossey-Alaoui K, Pluskota E, Szpak D, et al.: The Kindlin2-p53-SerpinB2 signaling axis is required for cellular senescence in breast cancer. Cell Death Dis. 2019; 10(8): 539

PubMed Abstract | Publisher Full Text | Free Full Text

17. Plow EF, Das M, Bialkowska K, et al.: Of Kindlins and Cancer. Discoveries (Craiova). 2016; 4(2): e59.

PubMed Abstract | Publisher Full Text | Free Full Text

18. Krenn PW, Koschmieder S, Fässler R: Kindlin-3 loss curbs chronic myeloid leukemia in mice by mobilizing leukemic stem cells from protective bone marrow niches. Proc Natl Acad Sci U S A. 2020; 117(39): 24326-35. PubMed Abstract | Publisher Full Text | Free Full Text | Faculty Opinions Recommendation

19. Lu P, Weaver VM, Werb Z: The extracellular matrix: A dynamic niche in cancer progression. J Cell Biol. 2012; 196(4): 395-406 PubMed Abstract | Publisher Full Text | Free Full Text

20. Panciera T, Citron A, Di Biagio D, et al:: Reprogramming normal cells into tumour precursors requires ECM stiffness and oncogene-mediated changes of cell mechanical properties. Nat Mater. 2020; 19(7): 797-806. PubMed Abstract | Publisher Full Text | Free Full Text | Faculty Opinions Recommendation

21. Mohammadi $\mathrm{H}$, Sahai $\mathrm{E}$ : Mechanisms and impact of altered tumour mechanics. Nat Cell Biol. 2018; 20(7): 766-74. PubMed Abstract | Publisher Full Text

22. Chakraborty S, Njah K, Pobbati AV, et al.: Agrin as a Mechanotransduction Signal Regulating YAP through the Hippo Pathway. Cell Rep. 2017; 18(10): 2464-2479.

PubMed Abstract | Publisher Full Text

23. $\mathrm{Ma} \mathrm{H}$, Wang J, Zhao X, et al.: Periostin Promotes Colorectal Tumorigenesis through Integrin-FAK-Src Pathway-Mediated YAP/TAZ Activation. Cell Rep. 2020; 30(3): 793-806.e6.

PubMed Abstract | Publisher Full Text | Faculty Opinions Recommendation

24. Miroshnikova YA, Rozenberg GI, Cassereau L, et al.: $\alpha .5 \beta 1$-Integrin promotes tension-dependent mammary epithelial cell invasion by engaging the fibronectin synergy site. Mol Biol Cell. 2017; 28(22): 2958-2977. PubMed Abstract | Publisher Full Text | Free Full Text

25. Barnes JM, Kaushik S, Bainer RO, et al.: A tension-mediated glycocalyx-integrin feedback loop promotes mesenchymal-like glioblastoma. Nat Cell Biol. 2018; 20(10): 1203-14.

PubMed Abstract | Publisher Full Text | Free Full Text

26. Follain G, Osmani N, Azevedo AS, et al.: Hemodynamic Forces Tune the Arrest, Adhesion, and Extravasation of Circulating Tumor Cells. Dev Cell. 2018; 45(1): 33-52.12.

PubMed Abstract | Publisher Full Text | Faculty Opinions Recommendation 
27. Osmani N, Follain G, García León MJ, et al:: Metastatic Tumor Cells Exploit Their Adhesion Repertoire to Counteract Shear Forces during Intravascular Arrest. Cell Rep. 2019; 28(10): 2491-2500.e5.

PubMed Abstract | Publisher Full Text | Faculty Opinions Recommendation

28. Velez DO, Tsui B, Goshia T, et al.: 3D collagen architecture induces a conserved migratory and transcriptional response linked to vasculogenic mimicry. Nat Commun. 2017; 8(1): 1651.

PubMed Abstract | Publisher Full Text | Free Full Text

29. de Franceschi $\mathrm{N}$, Hamidi $\mathrm{H}$, Alanko J, et al:: Integrin traffic - the update. J Cell Sci. 2015; 128(5): 839-52.

PubMed Abstract | Publisher Full Text | Free Full Text

30. Jones MC, Caswell PT, Norman JC: Endocytic recycling pathways: Emerging regulators of cell migration. Curr Opin Cell Biol. 2006; 18(5): 549-57. PubMed Abstract | Publisher Full Text

31. S Samarelli AV, Ziegler T, Meves A, et al:: Rabgap1 promotes recycling of active $\beta 1$ integrins to support effective cell migration. J Cell Sci. 2020; 133(18): jcs243683.

PubMed Abstract | Publisher Full Text | Free Full Text |

Faculty Opinions Recommendation

32. Howe EN, Burnette MD, Justice ME, et al:: Rab11b-mediated integrin recycling promotes brain metastatic adaptation and outgrowth. Nat Commun. 2020; 11(1): 3017.

PubMed Abstract | Publisher Full Text | Free Full Text |

Faculty Opinions Recommendation

33. Mana G, Clapero F, Panieri E, et al.: PPFIA1 drives active $\alpha 5 \beta 1$ integrin recycling and controls fibronectin fibrillogenesis and vascular morphogenesis. Nat Commun. 2016; 7: 13546.

PubMed Abstract | Publisher Full Text | Free Full Text | Faculty Opinions Recommendation

34. Sahgal P, Alanko J, Icha J, et al:: GGA2 and RAB13 promote activity-dependent B1-integrin recycling. J Cell Sci. 2019; 132(11): jcs233387. PubMed Abstract | Publisher Full Text

35. Sampayo RG, Toscani AM, Rubashkin MG, et al:: Fibronectin rescues estrogen receptor $\alpha$ from lysosomal degradation in breast cancer cells. $J$ Cell Biol. 2018; 217(8): 2777-98

PubMed Abstract | Publisher Full Text | Free Full Text |

Faculty Opinions Recommendation

36. Pontiggia O, Sampayo R, Raffo D, et al:: The tumor microenvironment modulates tamoxifen resistance in breast cancer: A role for soluble stroma factors and fibronectin through $\mathbf{\beta 1}$ integrin. Breast Cancer Res Treat. 2012 133(2): 459-71.

PubMed Abstract | Publisher Full Text | Free Full Text

37. Zhao G, Gong L, Su D, et al:: Cullin5 deficiency promotes small-cell lung cancer metastasis by stabilizing integrin $\beta 1$. J Clin Invest. 2019; 129(3): 972-87. PubMed Abstract | Publisher Full Text | Free Full Text | Faculty Opinions Recommendation

38. Alanko J, Mai A, Jacquemet G, et al:: Integrin endosomal signalling suppresses anoikis. Nat Cell Biol. 2015; 17(11): 1412-21. PubMed Abstract | Publisher Full Text | Free Full Text | Faculty Opinions Recommendation

39. Barrow-McGee R, Kishi N, Joffre C, et al.: Beta 1-integrin-c-Met cooperation reveals an inside-in survival signalling on autophagy-related endomembranes. Nat Commun. 2016; 7: 11942 .

PubMed Abstract | Publisher Full Text | Free Full Text

40. Möller A, Lobb RJ: The evolving translational potential of small extracellular vesicles in cancer. Nat Rev Cancer. 2020; 20(12): 697-709. PubMed Abstract | Publisher Full Text

41. CFuentes P, Sesé M, Guijarro PJ, et al:: ITGB3-mediated uptake of small extracellular vesicles facilitates intercellular communication in breast cancer cells. Nat Commun. 2020; 11(1): 4261. PubMed Abstract | Publisher Full Text | Free Full Text | Faculty Opinions Recommendation

42. Novo D, Heath N, Mitchell L, et al:: Mutant p53s generate pro-invasive niches by influencing exosome podocalyxin levels. Nat Commun. 2018; 9(1) 5069.

PubMed Abstract | Publisher Full Text | Free Full Text | Faculty Opinions Recommendation

43. Ivaska J, Heino J: Cooperation between integrins and growth factor receptors in signaling and endocytosis. Annu Rev Cell Dev Biol. 2011; 27: 291-320. PubMed Abstract | Publisher Full Text

44. Chen Z, Oh D, Dubey AK, et al.: EGFR family and Src family kinase interactions: Mechanics matters? Curr Opin Cell Biol. 2018; 51: 97-102. PubMed Abstract | Publisher Full Text

45. Moro L, Dolce L, Cabodi S, et al:: Integrin-induced epidermal growth factor (EGF) receptor activation requires c-Src and p130Cas and leads to phosphorylation of specific EGF receptor tyrosines. J Biol Chem. 2002; 277(11): 9405-14.

PubMed Abstract | Publisher Full Text | Faculty Opinions Recommendation
46. Saxena M, Liu S, Yang B, et al.: EGFR and HER2 activate rigidity sensing only on rigid matrices. Nat Mater. 2017; 16(7): 775-81. PubMed Abstract | Publisher Full Text | Free Full Text

47. Yang B, Lieu ZZ, Wolfenson $\mathrm{H}$, et al:: Mechanosensing Controlled Directly by Tyrosine Kinases. Nano Lett. 2016; 16(9): 5951-61. PubMed Abstract | Publisher Full Text | Free Full Text

48. S Shen M, Jiang YZ, Wei Y, et al:: Tinagl1 Suppresses Triple-Negative Breast Cancer Progression and Metastasis by Simultaneously Inhibiting Integrin/FAK and EGFR Signaling. Cancer Cell. 2019; 35(1): 64-80.e7.

PubMed Abstract | Publisher Full Text | Faculty Opinions Recommendation

49. Seguin L, Kato $S$, Franovic A, et al:: An integrin $\beta_{3}$-KRAS-RalB complex drives tumour stemness and resistance to EGFR inhibition. Nat Cell Biol. 2014; 16(5): 457-68.

PubMed Abstract | Publisher Full Text | Free Full Text

50. Seguin L, Camargo MF, Wettersten HI, et al:: Galectin-3, a Druggable Vulnerability for KRAS-Addicted Cancers. Cancer Discov. 2017; 7(12) 1464-1479.

PubMed Abstract | Publisher Full Text | Free Full Text

51. Mariotti A, Kedeshian PA, Dans M, et al.: EGF-R signaling through Fyn kinase disrupts the function of integrin alpha6beta4 at hemidesmosomes: Role in epithelial cell migration and carcinoma invasion. J Cell Biol. 2001; 155(3): 447-58.

PubMed Abstract | Publisher Full Text | Free Full Text

52. Trusolino L, Bertotti A, Comoglio PM: A signaling adapter function for alpha6beta4 integrin in the control of HGF-dependent invasive growth. Cell. 2001; 107(5): 643-54.

PubMed Abstract | Publisher Full Text

53. Guo W, Pylayeva Y, Pepe A, et al.: Beta 4 integrin amplifies ErbB2 signaling to promote mammary tumorigenesis. Cell. 2006; 126(3): 489-502. PubMed Abstract | Publisher Full Text | Faculty Opinions Recommendation

54. Santoro MM, Gaudino G, Marchisio PC: The MSP receptor regulates alpha6beta4 and alpha3beta1 integrins via 14-3-3 proteins in keratinocyte migration. Dev Cell. 2003; 5(2): 257-71.

PubMed Abstract | Publisher Full Text

55. Bertotti A, Comoglio PM, Trusolino L: Beta4 integrin activates a Shp2-Src signaling pathway that sustains HGF-induced anchorage-independent growth J Cell Biol. 2006; 175(6): 993-1003.

PubMed Abstract | Publisher Full Text | Free Full Text

56. Giancotti FG: Targeting integrin beta4 for cancer and anti-angiogenic therapy. Trends Pharmacol Sci. 2007; 28(10): 506-11.

PubMed Abstract | Publisher Full Text

57. Rainero E: Extracellular matrix internalization links nutrient signalling to invasive migration. Int J Exp Pathol. 2018; 99(1): 4-9. PubMed Abstract | Publisher Full Text | Free Full Text

58. Nazemi M, Rainero E: Cross-Talk Between the Tumor Microenvironment, Extracellular Matrix, and Cell Metabolism in Cancer. Front Oncol. 2020; 10: 239. PubMed Abstract | Publisher Full Text | Free Full Text

59. Kalaany NY, Sabatini DM: Tumours with PI3K activation are resistant to dietary restriction. Nature. 2009; 458(7239): 725-31. PubMed Abstract | Publisher Full Text | Free Full Text | Faculty Opinions Recommendation

60. Nuranen T, Selfors LM, Worster DT, et al:: Inhibition of PI3K/mTOR leads to adaptive resistance in matrix-attached cancer cells. Cancer Cell. 2012; 21(2): 227-39.

PubMed Abstract | Publisher Full Text | Free Full Text | Faculty Opinions Recommendation

61. Muranen T, Iwanicki MP, Curry NL, et al:: Starved epithelial cells uptake extracellular matrix for survival. Nat Commun. 2017; 8: 13989. PubMed Abstract | Publisher Full Text | Free Full Text | Faculty Opinions Recommendation

62. Stewart RL, O'Connor KL: Clinical significance of the integrin $\alpha 6 \beta 4$ in human malignancies. Lab Invest. 2015; 95(9): 976-86. PubMed Abstract | Publisher Full Text | Free Full Text | Faculty Opinions Recommendation

63. Rainero E, Howe JD, Caswell PT, et al:: Ligand-Occupied Integrin Internalization Links Nutrient Signaling to Invasive Migration. Cell Rep. 2015; 10(3): 398-413. PubMed Abstract | Publisher Full Text

64. Georgiadou M, Lilja J, Jacquemet G, et al:: AMPK negatively regulates tensin-dependent integrin activity. J Cell Biol. 2017; 216(4): 1107-21. PubMed Abstract | Publisher Full Text | Free Full Text Faculty Opinions Recommendation

65. Georgiadou M, Ivaska J: Tensins: Bridging AMP-Activated Protein Kinase with Integrin Activation. Trends Cell Biol. 2017; 27(10): 703-11. PubMed Abstract | Publisher Full Text

66. Bui T, Rennhack J, Mok S, et al.: Functional Redundancy between $\beta 1$ and $\beta 3$ Integrin in Activating the IR/Akt/mTORC1 Signaling Axis to Promote ErbB2Driven Breast Cancer. Cell Rep. 2019; 29(3): 589-602.e6. PubMed Abstract | Publisher Full Text 
67. Cosset É, IImjärv S, Dutoit V, et al:: Glut3 Addiction Is a Druggable Vulnerability for a Molecularly Defined Subpopulation of Glioblastoma. Cancer Cell. 2017; 32(6): 856-868.e5.

PubMed Abstract | Publisher Full Text | Free Full Text

68. Elia I, Rossi M, Stegen S, et al.: Breast cancer cells rely on environmental pyruvate to shape the metastatic niche. Nature. 2019; 568(7750): 117-21. PubMed Abstract | Publisher Full Text | Free Full Text | Faculty Opinions Recommendation

69. de Palma M, Biziato D, Petrova TV: Microenvironmental regulation of tumour angiogenesis. Nat Rev Cancer. 2017; 17(8): 457-74. PubMed Abstract | Publisher Full Text

70. Mana G, Valdembri D, Serini G: Conformationally active integrin endocytosis and traffic: Why, where, when and how? Biochem Soc Trans. 2020; 48(1): 83-93. PubMed Abstract | Publisher Full Text | Free Full Text

71. Nichol D, Stuhlmann H: EGFL7: A unique angiogenic signaling factor in vascular development and disease. Blood. 2012; 119(6): 1345-52. PubMed Abstract | Publisher Full Text | Free Full Text

72. Dudvarski Stanković N, Bicker F, Keller S, et al:: EGFL7 enhances surface expression of integrin $\alpha_{5} \beta$, to promote angiogenesis in malignant brain tumors. EMBO Mol Med. 2018; 10(9): e8420.

PubMed Abstract | Publisher Full Text | Free Full Text

73. Bordeleau F, Mason BN, Lollis EM, et al.: Matrix stiffening promotes a tumor vasculature phenotype. Proc Natl Acad Sci U S A. 2017; 114(3): 492-7. PubMed Abstract | Publisher Full Text | Free Full Text

74. Njah K, Chakraborty S, Qiu B et al: A Role of Agrin in Maintaining the Stability of Vascular Endothelial Growth Factor Receptor-2 during Tumor Angiogenesis. Cell Rep. 2019; 28(4): 949-965.e7. PubMed Abstract | Publisher Full Text

75. L Li L, Xiong WC, Mei L: Neuromuscular Junction Formation, Aging, and Disorders. Annu Rev Physiol. 2018; 80: 159-88. PubMed Abstract | Publisher Full Text | Faculty Opinions Recommendation

76. Wong PP, Muñoz-Félix JM, Hijazi M, et al:: Cancer Burden Is Controlled by Mural Cell-p3-Integrin Regulated Crosstalk with Tumor Cells. Cell. 2020; 181(6): 1346-1363.e21.

PubMed Abstract | Publisher Full Text | Faculty Opinions Recommendation

77. Dongre A, Weinberg RA: New insights into the mechanisms of epithelialmesenchymal transition and implications for cancer. Nat Rev Mol Cell Biol. 2019; 20(2): 69-84

PubMed Abstract | Publisher Full Text

78. Dayton TL, Jacks T, Vander Heiden MG: PKM2, cancer metabolism, and the road ahead. EMBO Rep. 2016; 17(12): 1721-30. PubMed Abstract | Publisher Full Text | Free Full Text

79. Wang C, Zhang S, Liu J, et al:: Secreted Pyruvate Kinase M2 Promotes Lung Cancer Metastasis through Activating the Integrin Beta1/FAK Signaling Pathway. Cell Rep. 2020; 30(6): 1780-1797.e6.

PubMed Abstract | Publisher Full Text | Faculty Opinions Recommendation

80. C Gerarduzzi C, Hartmann U, Leask A, et al:: The Matrix Revolution: Matricellular Proteins and Restructuring of the Cancer Microenvironment. Cancer Res. 2020; 80(13): 2705-17.

PubMed Abstract | Publisher Full Text | Faculty Opinions Recommendation

81. Sangaletti S, Tripodo C, Santangelo A, et al:: Mesenchymal Transition of HighGrade Breast Carcinomas Depends on Extracellular Matrix Control of Myeloid Suppressor Cell Activity. Cell Rep. 2016; 17(1): 233-48. PubMed Abstract | Publisher Full Text

82. Wilson MM, Weinberg RA, Lees JA, et al.: Emerging Mechanisms by which EMT Programs Control Stemness. Trends Cancer. 2020; 6(9): 775-80. PubMed Abstract | Publisher Full Text | Faculty Opinions Recommendation

83. Sun $\mathrm{Q}$, Lesperance J, Wettersten $\mathrm{H}$, et al:: Proapoptotic PUMA targets stem-like breast cancer cells to suppress metastasis. J Clin Invest. 2018; 128(1): 531-44. PubMed Abstract | Publisher Full Text | Free Full Text

84. Gabbiani G, Ryan GB, Majne G: Presence of modified fibroblasts in granulation tissue and their possible role in wound contraction. Experientia. 1971; 27(5): 549-50.

PubMed Abstract | Publisher Full Text

85. Sappino AP, Skalli O, Jackson B, et al:: Smooth-muscle differentiation in stromal cells of malignant and non-malignant breast tissues. Int J Cancer. 1988; 41(5): 707-12.

PubMed Abstract | Publisher Full Text

86. S Sahai E, Astsaturov I, Cukierman E, et al.: A framework for advancing our understanding of cancer-associated fibroblasts. Nat Rev Cancer. 2020; 20(3): 174-86.

PubMed Abstract | Publisher Full Text | Free Full Text |

Faculty Opinions Recommendation

87. Attieh $Y$, Clark AG, Grass $C$, et al: Cancer-associated fibroblasts lead tumor invasion through integrin-(33-dependent fibronectin assembly. J Cell Biol. 2017; 216(11): 3509-20.

PubMed Abstract | Publisher Full Text | Free Full Text

88. Erdogan B, Ao M, White LM, et al:: Cancer-associated fibroblasts promote directional cancer cell migration by aligning fibronectin. J Cell Biol. 2017;
216(11): 3799-816

PubMed Abstract | Publisher Full Text | Free Full Text |

Faculty Opinions Recommendation

89. Saunders JT, Schwarzbauer JE: Fibronectin matrix as a scaffold for procollagen proteinase binding and collagen processing. Mol Biol Cell. 2019; 30(17) 2218-26.

PubMed Abstract | Publisher Full Text | Free Full Text

90. Primac I, Maquoi E, Blacher S, et al:: Stromal integrin $\alpha 11$ regulates PDGFR- $\beta$ signaling and promotes breast cancer progression. J Clin Invest. 2019; 129(11): 4609-28.

PubMed Abstract | Publisher Full Text | Free Full Text

91. Pereira ER, Kedrin D, Seano G, et al.: Lymph node metastases can invade local blood vessels, exit the node, and colonize distant organs in mice. Science. 2018; 359(6382): 1403-1407.

PubMed Abstract | Publisher Full Text | Free Full Text |

Faculty Opinions Recommendation

92. Brown M, Assen FP, Leithner A, et al.: Lymph node blood vessels provide exit routes for metastatic tumor cell dissemination in mice. Science. 2018; 359(6382): 1408-1411.

PubMed Abstract | Publisher Full Text

93. Padera TP, Meijer EFJ, Munn LL: The Lymphatic System in Disease Processes and Cancer Progression. Annu Rev Biomed Eng. 2016; 18: 125-58. PubMed Abstract | Publisher Full Text | Free Full Text

94. Commerford CD, Dieterich LC, He Y, et al:: Mechanisms of Tumor-Induced Lymphovascular Niche Formation in Draining Lymph Nodes. Cell Rep. 2018; 25(13): 3554-3563.e4.

PubMed Abstract | Publisher Full Text | Free Full Text

95. Evans R, Flores-Borja F, Nassiri S, et al:: Integrin-Mediated Macrophage Adhesion Promotes Lymphovascular Dissemination in Breast Cancer. Cell Rep. 2019; 27(7): 1967-1978.e4

PubMed Abstract | Publisher Full Text | Free Full Text

96. DEr EE, Valiente M, Ganesh K, et al.: Pericyte-like spreading by disseminated cancer cells activates YAP and MRTF for metastatic colonization. Nat Cell Biol. 2018; 20(8): 966-978.

PubMed Abstract | Publisher Full Text | Free Full Text |

Faculty Opinions Recommendation

97. Y Yao H, Price TT, Cantelli G, et al.: Leukaemia hijacks a neural mechanism to invade the central nervous system. Nature. 2018; 560(7716): 55-60. PubMed Abstract | Publisher Full Text | Faculty Opinions Recommendation

98. Seano G, Jain RK: Vessel co-option in glioblastoma: Emerging insights and opportunities. Angiogenesis. 2020; 23(1): 9-16.

PubMed Abstract | Publisher Full Text | Free Full Text

99. Gang EJ, Kim HN, Hsieh YT, et al.: Integrin $\alpha 6$ mediates the drug resistance of acute lymphoblastic B-cell leukemia. Blood. 2020; 136(2): 210-223. PubMed Abstract | Publisher Full Text | Free Full Text

100. Carlson P, Dasgupta A, Grzelak CA, et al:: Targeting the perivascular niche sensitizes disseminated tumour cells to chemotherapy. Nat Cell Biol. 2019; 21(2): 238-250.

PubMed Abstract | Publisher Full Text | Free Full Text

101. Kuninty PR, Bansal R, de Geus SWL, et al:: ITGA5 inhibition in pancreatic stellate cells attenuates desmoplasia and potentiates efficacy of chemotherapy in pancreatic cancer. Sci Adv. 2019; 5(9): eaax2770. PubMed Abstract | Publisher Full Text | Free Full Text

102. Dickreuter $\mathrm{E}$, Eke I, Krause $\mathrm{M}$, et al.: Targeting of $\beta 1$ integrins impairs DNA repair for radiosensitization of head and neck cancer cells. Oncogene. 2016; 35(11): 1353-62. PubMed Abstract | Publisher Full Text

103. Haeger A, Alexander S, Vullings M, et al.: Collective cancer invasion forms an integrin-dependent radioresistant niche. J Exp Med. 2020; 217(1): e20181184

PubMed Abstract | Publisher Full Text | Free Full Text | Faculty Opinions Recommendation

104. Alday-Parejo B, Stupp R, Rüegg C: Are Integrins Still Practicable Targets for Anti-Cancer Therapy? Cancers (Basel). 2019; 11(7): 978 PubMed Abstract | Publisher Full Text | Free Full Text

105. Danhier F, Le Breton A, Préat V: RGD-based strategies to target alpha(v) beta(3) integrin in cancer therapy and diagnosis. Mol Pharm. 2012; 9(11): 2961-73. PubMed Abstract | Publisher Full Text

106. Doolittle E, Peiris PM, Doron G, et al:: Spatiotemporal Targeting of a Dual-Ligand Nanoparticle to Cancer Metastasis. ACS Nano. 2015; 9(8): 8012-21. PubMed Abstract | Publisher Full Text | Free Full Text

107. Shi S, Zhou M, Li X, et al:: Synergistic active targeting of dually integrin $\alpha v \beta$ 3/CD44-targeted nanoparticles to B16F10 tumors located at different sites of mouse bodies. J Control Release. 2016; 235: 1-13. PubMed Abstract | Publisher Full Text

108. Yu X, Gao D, Gao L, et al.: Inhibiting Metastasis and Preventing Tumor Relapse by Triggering Host Immunity with Tumor-Targeted Photodynamic Therapy Using Photosensitizer-Loaded Functional Nanographenes. ACS Nano. 2017; 11(10): 10147-58

PubMed Abstract | Publisher Full Text 
109. Liu Z, Wang F: Development of RGD-based radiotracers for tumor imaging and therapy: Translating from bench to bedside. Curr Mol Med. 2013; 13(10): 1487-505.

PubMed Abstract | Publisher Full Text

110. Zhao H, Gao H, Zhai L, et al:: $(99 \mathrm{~m}) \mathrm{Tc}-\mathrm{HisoDGR}$ as a Potential SPECT Probe for Orthotopic Glioma Detection via Targeting of Integrin a5p1. Bioconjug Chem. 2016; 27(5): 1259-66. PubMed Abstract | Publisher Full Text

111. D'Alessandria $\mathrm{C}$, Pohle $\mathrm{K}$, Rechenmacher $\mathrm{F}$, et al:: In vivo biokinetic and metabolic characterization of the ${ }^{68} \mathrm{Ga}$-labelled $\alpha 5 \beta 1$-selective peptidomimetic FR366. Eur J Nucl Med Mol Imaging. 2016; 43(5): 953-63. PubMed Abstract | Publisher Full Text

112. Nieberler $\mathrm{M}$, Reuning $\mathrm{U}, \mathrm{Kessler} \mathrm{H}$, et al.: Fluorescence imaging of invasive head and neck carcinoma cells with integrin avp6-targeting RGD-peptides: An approach to a fluorescence-assisted intraoperative cytological assessment of bony resection margins. Br J Oral Maxillofac Surg. 2018; 56(10): 972-978. PubMed Abstract | Publisher Full Text

113. Mellman I, Coukos G, Dranoff G: Cancer immunotherapy comes of age. Nature. 2011; 480(7378): 480-9. PubMed Abstract | Publisher Full Text | Free Full Text

114. Jin H, Su J, Garmy-Susini B, et al.: Integrin alpha4beta1 promotes monocyte trafficking and angiogenesis in tumors. Cancer Res. 2006; 66(4): 2146-52. PubMed Abstract | Publisher Full Text

115. Dipersio CM, van de Water L: Integrin Regulation of CAF Differentiation and Function. Cancers (Basel). 2019; 11(5): 715 PubMed Abstract | Publisher Full Text | Free Full Text

116. Whilding LM, Vallath $S$, Maher $\mathrm{J}$ : The integrin $\alpha \mathrm{v} \beta 6$ : a novel target for CAR T-cell immunotherapy? Biochem Soc Trans. 2016; 44(2): 349-55. PubMed Abstract | Publisher Full Text

117. $\mathrm{Li} \mathrm{S}$, Liu M, Do MH, et al:: Cancer immunotherapy via targeted TGFsignalling blockade in $\mathrm{T}_{\mathrm{H}}$ cells. Nature. 2020; 587(7832): 121-5. PubMed Abstract | Publisher Full Text | Faculty Opinions Recommendation

118. O'Day S, Pavlick A, Loquai C, et al.: A randomised, phase II study of intetumumab, an anti- $\alpha_{\mathrm{v}}$-integrin $\mathrm{mAb}$ alone and with dacarbazine in stage IV melanoma. Br J Cancer. 2011; 105(3): 346-52. PubMed Abstract | Publisher Full Text | Free Full Text

119. Heidenreich A, Rawal SK, Szkarlat K, et al.: A randomized, double-blind, multicenter, phase 2 study of a human monoclonal antibody to human $\alpha v$ integrins (intetumumab) in combination with docetaxel and prednisone for the first-line treatment of patients with metastatic castration-resistant prostate cancer. Ann Oncol. 2013; 24(2): 329-36. PubMed Abstract | Publisher Full Text

120. Élez E, Kocáková I, Höhler T, et al:: Abituzumab combined with cetuximab plus irinotecan versus cetuximab plus irinotecan alone for patients with KRAS wildtype metastatic colorectal cancer: The randomised phase I/II POSEIDON trial. Ann Oncol. 2015; 26(1): 132-40. PubMed Abstract | Publisher Full Text

121. Gramoun A, Shorey S, Bashutski JD, et al.: Effects of Vitaxin, a novel therapeutic in trial for metastatic bone tumors, on osteoclast functions in vitro. J Cell Biochem. 2007; 102(2): 341-52. PubMed Abstract | Publisher Full Text

122. Posey JA, Khazaeli MB, DelGrosso A, et al.: A pilot trial of Vitaxin, a humanized anti-vitronectin receptor (anti $\alpha_{v} \beta_{3}$ ) antibody in patients with metastatic cancer. Cancer Biother Radiopharm. 2001; 16(2): 125-32. PubMed Abstract | Publisher Full Text

123. Hersey $\mathrm{P}$, Sosman J, O'Day S, et al.: A randomized phase 2 study of etaracizumab, a monoclonal antibody against integrin alpha(v)beta(3), + or - dacarbazine in patients with stage IV metastatic melanoma. Cancer. 2010; 116(6): 1526-34

PubMed Abstract | Publisher Full Text

124. Almokadem S, Belani CP: Volociximab in cancer. Expert Opin Biol Ther. 2012; 12(2): 251-7. PubMed Abstract | Publisher Full Text

125. Vermorken JB, Peyrade F, Krauss J, et al:: Cisplatin, 5-fluorouracil, and cetuximab (PFE) with or without cilengitide in recurrent/metastatic squamous cell carcinoma of the head and neck: Results of the randomized phase $1 / I I$ ADVANTAGE trial (phase II part). Ann Oncol. 2014; 25(3): 682-8. PubMed Abstract | Publisher Full Text | Free Full Text

126. Vansteenkiste J, Barlesi F, Waller CF, et al:: Cilengitide combined with cetuximab and platinum-based chemotherapy as first-line treatment in advanced nonsmall-cell lung cancer (NSCLC) patients: Results of an open-label, randomized, controlled phase II study (CERTO). Ann Oncol. 2015; 26(8): 1734-40. PubMed Abstract | Publisher Full Text

127. Nabors LB, Mikkelsen T, Hegi ME, et al.: A safety run-in and randomized phase 2 study of cilengitide combined with chemoradiation for newly diagnosed glioblastoma (NABTT 0306). Cancer. 2012; 118(22): 5601-7. PubMed Abstract | Publisher Full Text | Free Full Text

128. Reardon DA, Fink KL, Mikkelsen T, et al.: Randomized phase II study of cilengitide, an integrin-targeting arginine-glycine-aspartic acid peptide, in recurrent glioblastoma multiforme. J Clin Oncol. 2008; 26(34): 5610-7. PubMed Abstract | Publisher Full Text

129. Alva A, Slovin S, Daignault S, et al:: Phase II study of cilengitide (EMD 121974 , NSC 707544) in patients with non-metastatic castration resistant prostate cancer, $\mathrm{NCl}-6735$. A study by the DOD/PCF prostate cancer clinical trials consortium. Invest New Drugs. 2012; 30(2): 749-57. PubMed Abstract | Publisher Full Text | Free Full Text

130. C Stupp R, Hegi ME, Neyns B, et al.: Phase I/lla study of cilengitide and temozolomide with concomitant radiotherapy followed by cilengitide and temozolomide maintenance therapy in patients with newly diagnosed glioblastoma. J Clin Oncol. 2010; 28(16): 2712-8. PubMed Abstract | Publisher Full Text | Faculty Opinions Recommendation

131. Nabors LB, Fink KL, Mikkelsen T, et al.: Two cilengitide regimens in combination with standard treatment for patients with newly diagnosed glioblastoma and unmethylated MGMT gene promoter: Results of the open-label, controlled, randomized phase II CORE study. Neuro Oncol. 2015; 17(5): 708-17. PubMed Abstract | Publisher Full Text | Free Full Text

132. Cianfrocca ME, Kimmel KA, Gallo J, et al.: Phase 1 trial of the antiangiogenic peptide ATN-161 (Ac-PHSCN-NH(2)), a beta integrin antagonist, in patients with solid tumours. Br J Cancer. 2006; 94(11): 1621-6. PubMed Abstract | Publisher Full Text | Free Full Text

133. Sheldrake HM, Patterson LH: Strategies to inhibit tumor associated integrin receptors: Rationale for dual and multi-antagonists. J Med Chem. 2014; 57(15): 6301-15.

PubMed Abstract | Publisher Full Text 